\title{
Application of Behavioral Counseling with Modeling Techniques and Social Skill to Improve Self Change
}

\author{
Ni Nyoman Sri Agustini Andayani ${ }^{\left.1^{*}\right)}$, I Ketut Dharsana ${ }^{2}$, Kadek Suranata ${ }^{3}$ \\ ${ }^{123}$ Department Guidance and Counseling, Universitas Pendidikan Ganesha, Singaraja, Bali. \\ *Corresponding author, e-mail: srixagustini23@gmail.com
}

Received 2020-05-07;

Revised 2020-05-10;

Accepted 2020-05-15;

Published Online 2020-05-30

\section{Conflict of Interest}

Disclosures:

The authors declare that they

have no significant competing

financial, professional or

personal interests that might have

influenced the performance or

presentation of the work

described in this manuscript.

\begin{abstract}
The purpose of this study was to improve the character of SMK Negeri 3 Denpasar Students. The low character of self-change of students is very interesting to be discussed and disclosed in a research study. This type of research is Experimental Research, with the design of pretest-group control group design. This research population is all class $\mathrm{X}$ of SMK Negeri 3 Denpasar. A sample of 102 students was taken randomly from the class and from the results of the distribution of self-change questionnaires, which were calculated using the $\mathrm{T}$ formula. The results of modeling techniques and social skills techniques showed that social skills techniques were effective in increasing self-change characteristics, while Modeling techniques were not effective change. This result is evidenced by the value of Fcount obtained at $29.944 p<0.05$. The results shown there are differences in the effectiveness of behavioral counseling between modeling techniques and social Skill techniques to enhance self-change.
\end{abstract}

Keywords: Self Change, Behavioral Counseling, Modeling Techniques, Social Skills Training Techniques

\section{Introduction}

Students are individuals who are in the process of developing which is developing toward maturity or independence. To reach this maturity, individuals need guidance and counseling services because they still lack understanding and insight about themselves and their environment, as well as experience in determining the direction of their lives. (Purwanto, Zaenudin, Anggoro, Hidayat, \& Aisyah, 2016) 
Based on the results of observations and interviews of researchers of students of class X SMK N 3 Denpasar, about the pleasure of traveling or hobbies traveling and meeting new people, male students showed more pleasure than female students. Besides that, also from the results of observations, some of the students were female students who were more aggressive in adding new experiences by changing them in their daily lives. Male students in their behavior showed less have the challenge of finding a new learning experience and changing it every day. The character of the call with the character of Change.

In the big Indonesian dictionary, it is said that the word change, which comes from English, is then translated into Indonesian, that is, change means to be new, to have a new perspective.

Furthermore, in the opinion of experts, it is stated that self-change is a person who can make new changes in the provision of guidance and counseling services, and seeks to consult with others relating to the difficulties faced (Dharsana, 2015) But previously mentioned that self-change is a need to make changes include something new and different, travel, meet new people, look for new experiences that change every day (Dharsana, 2013: 2)

From the opinion above, the researcher can conclude that self-change is a person's ability to make changes in a new direction, and change for the better, or become new and change from before. From the definition of self-change that was stated earlier, then self-change contains indicators, namely:(a)Something new and different, (b)Travel to new places,(c)meet new people, (d)Looking for new experiences and change them every day.

The following will be explained by each indicator as follows: (a)Something new and different is the courage to try everything new and different to add experience,(b)Traveling is a traveling activity by visiting new places to increase knowledge of newly visited places.(c)Meeting new people is meeting new people who are not yet known to add more experience, (d)Finding new experiences and changing them every day is trying new things and being brave and brave to change existing things to add experience and insight (Dharsana, 2013: 2)

Self Change can be interfered with in three ways, namely: (1) education, (2) counseling guidance, (3) extracurricular. Of the three interfaces, they have their weaknesses and strengths that can be used to intervene in the self-change. In this case, the researcher chooses counseling guidance to intervene in the self, the reason is that counseling guidance is a field of research expertise. Counseling guidance has 2 words of guidance and counseling. Guidance is the process of interfering with a character or a problem by a counselor in counseling to achieve his character's approach (Dharsana, 2018).

So in this study researchers used definition as a process of interfering with self-change. Counseling is the process of intervention using counseling theory and counseling techniques to improve the self or character of groups of people or individuals (Dharsana, 2018).

In this study, researchers chose counseling as an intervention process to improve self-change.

There are many counseling theories that can be used to provide intervention processes, and in this study, the researcher drops on Behavioral theory The emphasis is on behaviors that can be defined operationally can be observed and can be measured. And this approach can be used in increasing the character of change in students who have not been able to adapt to new environments, or new places, meet new people, travel, and gain new experiences that are changed every day, for the sake of improving life in the future. (Purwanto et al., 2016)

In this study, researchers made choices on counseling techniques, i.e.(1) Modeling and techniques (2) Social Skills Training Techniques. Bandura (1969) states that learning that can be obtained through direct experience can also be obtained indirectly by observing the behavior of others along with the consequences.

Bandura (1969) states that learning that can be obtained through direct experience can also be obtained indirectly by observing the behavior of others along with the consequences. Social Skills Training is a process of learning in improving one's ability to increase the ability to interact with others in social contexts that are socially acceptable and valued. This involves the ability to initiate and maintain positive and mutually beneficial interactions. Social Skills Training Techniques used in this study are the reasons for saying that this technique has the aim of assisting clients in their efforts to improve their self-impaired skills in building relationships with others, by train client skills that will be used later in relationships with others and the environment (Maharani \& Damayanti, 2012) 
Students are individuals who are in the process of developing which is developing toward maturity or independence. To reach this maturity, individuals need guidance and counseling services because they still lack understanding and insight about themselves and their environment, as well as experience in determining the direction of their lives. (Purwanto, Zaenudin, Anggoro, Hidayat, \& Aisyah, 2016)

Based on the results of observations and interviews of researchers of students of class X SMK N 3 Denpasar, about the pleasure of traveling or hobbies traveling and meeting new people, male students showed more pleasure than female students. Besides that, also from the results of observations, some of the students were female students who were more aggressive in adding new experiences by changing them in their daily lives. Male students in their behavior showed less have the challenge of finding a new learning experience and changing it every day.

In the big Indonesian dictionary, it is said that the word change, which comes from English, is then translated into Indonesian, that is, change means to be new, to have a new perspective. Furthermore, in the opinion of experts, it is stated that self-change is a person who can make new changes in the provision of guidance and counseling services, and seeks to consult with others relating to the difficulties faced (Dharsana, 2015) But previously mentioned that self-change is a need to make changes include something new and different, travel, meet new people, look for new experiences that change every day (Dharsana, 2013: 2)

From the opinion above, the researcher can conclude that self-change is a person's ability to make changes in a new direction, and change for the better, or become new and change from before. From the definition of self-change that was stated earlier, then self-change contains indicators, namely:(a)Something new and different, (b)Travel to new places,(c)meet new people, (d)Looking for new experiences and change them every day.

The following will be explained by each indicator as follows: (a)Something new and different is the courage to try everything new and different to add experience,(b)Traveling is a traveling activity by visiting new places to increase knowledge of newly visited places.(c)Meeting new people is meeting new people who are not yet known to add more experience, (d)Finding new experiences and changing them every day is trying new things and being brave and brave to change existing things to add experience and insight (Dharsana, 2013: 2)

Self Change can be interfered with in three ways, namely: (1) education, (2) counseling guidance, (3) extracurricular. Of the three interfaces, they have their weaknesses and strengths that can be used to intervene in the self-change. In this case, the researcher chooses counseling guidance to intervene in the self, the reason is that counseling guidance is a field of research expertise. Counseling guidance has 2 words of guidance and counseling. Guidance is the process of interfering with a character or a problem by a counselor in counseling to achieve his character's approach (Dharsana, 2018).

So in this study researchers used definition as a process of interfering with self-change. Counseling is the process of intervention using counseling theory and counseling techniques to improve the self or character of groups of people or individuals (Dharsana, 2018). In this study, researchers chose counseling as an intervention process to improve self-change.

There are many counseling theories that can be used to provide intervention processes, and in this study, the researcher drops on Behavioral theory The emphasis is on behaviors that can be defined operationally can be observed and can be measured. And this approach can be used in increasing the character of change in students who have not been able to adapt to new environments, or new places, meet new people, travel, and gain new experiences that are changed every day, for the sake of improving life in the future. (Purwanto et al., 2016)

In this study, researchers made choices on counseling techniques, i.e.(1) Modeling and techniques (2) Social Skills Training Techniques. Bandura (1969) states that learning that can be obtained through direct experience can also be obtained indirectly by observing the behavior of others along with the consequences.

Social Skills Training is a process of learning in improving one's ability to increase the ability to interact with others in social contexts that are socially acceptable and valued. This involves the ability to initiate and maintain positive and mutually beneficial interactions. Social Skills Training Techniques used in this 
study are the reasons for saying that this technique has the aim of assisting clients in their efforts to improve their self-impaired skills in building relationships with others, by train client skills that will be used later in relationships with others and the environment (Maharani \& Damayanti, 2012)

Social skills training is designed to improve the ability to communicate and social skills for someone who has difficulty interacting, including the skills to give praise, complaint because they do not agree, reject the requests of others, exchange experiences, ask for personal rights, give advice to others, problem-solving encountered, in collaboration with others, and several other behaviors that are not owned by the client (Michelson, 1985 in Maharani \& Damayanti, 2012)

Based on the description above, then as an effort to improve Self Change, researchers use a Behavioral approach so that it is packaged in the research title "Application of Behavioral Counseling with Modeling Techniques and Social Skills Training Techniques to Develop Self Change in Class X students of SMK Negeri 3 Denpasar. It is hoped that the results of the study will be able to be used and used in developing students' self-change characters following the objectives of this study.

Social skills training is designed to improve the ability to communicate and social skills for someone who has difficulty interacting, including the skills to give praise, complaint because they do not agree, reject the requests of others, exchange experiences, ask for personal rights, give advice to others, problem-solving encountered, in collaboration with others, and several other behaviors that are not owned by the client (Michelson, 1985 in Maharani \& Damayanti, 2012)

Based on the description above, then as an effort to improve Self Change, researchers use a Behavioral approach so that it is packaged in the research title "Application of Behavioral Counseling with Modeling Techniques and Social Skills Training Techniques to Develop Self Change in Class X students of SMK Negeri 3 Denpasar. It is hoped that the results of the study will be able to be used and used in developing students' self-change characters following the objectives of this study.

\section{Method}

This research is an experimental study involving 3 groups, namely two experimental groups and one control group. This study was designed by using questionnaires as pre-test and post-test, as a comparison of results before and after treatment was given to students, called the pretest/posttest control group design.

The population used in this study were all students of class $\mathrm{X}$ all majors, namely Hospitality Accommodation, Food, Beauty and Clothing in SMK N 3 Denpasar, except for class X Food A and Class $\mathrm{X}$ Hospitality A Accommodation which currently exists in industrial class whose existence is in the Industrial World.

Samples were taken randomly from the results of the questionnaire distributed and had low selfchange. Then obtained data of 34 Class X Food E students as experimental group 1 who will be subjected to action with modeling techniques, and X Food $\mathrm{F}$ as an Experiment Group 2 to be intervened with social skills techniques and another experimental group as a control group is class $\mathrm{X}$ Catering $\mathrm{C}$.

To support the completeness component for this study, researchers also used a diary that was made to measure changes in student character related to the four indicators of self-change, which were given to students when before and after the treatment was carried out and monitored through the acquisition of scores for each student's diary. Furthermore, the data analysis technique is quantitative descriptive and the calculation results of the analysis are adjusted to the desired .

\section{Results and Discussion}

The initial step of this study was the distribution of questionnaires that had been tested for validity and reliability were very high to all students who became the population in this study as many as 556 students, then the results of this pretest were recapitulated and categorized according to their categories namely, 
high, high, medium, low and very low. From the pre-test data, three classes of the experiment were taken as experiment 1, experimental group2, and control group.

In Providing Treatment of Classical Guidance. Group guidance, group counseling and individual counseling, each time a meeting is discussed about the diary score that was previously assigned to students to fill in, and each time the meeting continues to fill in the diary, fill in the reflection sheet, then the results of each diary meeting are given a score, and The score is included in the tabulation score to see daily, weekly and monthly developments.

This research was conducted through 4 Guidance services. The description of the results of the counseling process, in general, is as follows:

\section{a. Classical Guidance}

In general, the guidance process is classically carried out when the treatment takes place in each group. Gradually students can minimize self-change. The results of each treatment in classical guidance will be analyzed in this study.

\section{b. Group counseling}

After the classical service is implemented, students are then recommended to attend group guidance. All group participants play an active role in the group's mentoring activities. From this activity, the researchers looked at who were students who had been able to show an increase in self-change and who had not. Students who have not been able to improve self-change will be recommended to attend group counseling.

\section{c. Group Counseling}

Group counseling activities involve students who have the same problem then formed into a group to provide treatments for those who cannot understand self-change.

\section{d. Individual Counseling}

In observing group counseling activities, researchers have been able to see who are the students who can be recommended in individual counseling activities. The student then personally and face to face talk with the counselor to help the problems faced by him.

In Providing Treatment of Classical Guidance. Group guidance, group counseling and individual counseling, each time a meeting is discussed about the diary score that was previously assigned to students to fill in, and each time the meeting continues to fill in the diary, fill in the reflection sheet, then the results of each diary meeting are given a score, and The score is included in the tabulation score to see daily weekly and monthly developments.

The development of experimental group 1 data that will be treated with behavioral counseling with modeling techniques can be seen in table 1 .

Table 1. Experiment Group Data Diary 1

\begin{tabular}{|c|c|c|c|c|c|c|c|c|c|}
\hline \multirow{2}{*}{ No } & & \multicolumn{7}{|c|}{ Day } & \multirow[t]{2}{*}{ Average } \\
\hline & & 1 & 2 & 3 & 4 & 5 & 6 & 7 & \\
\hline 1 & M1 & 4,85 & 5 & 5,23 & 5,85 & 6,5 & 7,23 & 8,08 & 6,11 \\
\hline 2 & M2 & 8,44 & 9,82 & 11,2 & 12,58 & 13,97 & 15,35 & 16,73 & 12,58 \\
\hline 3 & M3 & 16,73 & 18,41 & 20,08 & 21,76 & 23,44 & 25,11 & 26,79 & 21,76 \\
\hline 4 & M4 & 26,79 & 28,52 & 30,26 & 32 & 33,731 & 35,47 & 37,2 & 32,00 \\
\hline 5 & M5 & 37,2 & 38,41 & 39,61 & 40,82 & 42,02 & 43,23 & 44,44 & 40,82 \\
\hline 6 & M6 & 44,44 & 45,56 & 46,67 & 47,79 & 48,91 & 50,02 & 51,14 & 47,79 \\
\hline
\end{tabular}

Based on the daily scores in table 1 above, the Experiment 1 group diary given behavior counseling with modeling techniques can be visualized in the form of a developmental graph as follows. 


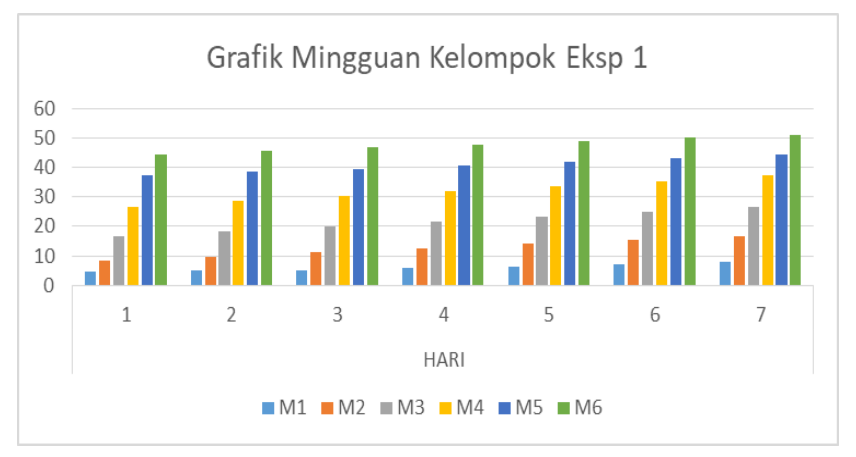

Fig. 1 Weekly Graph of Diary Score in Experiment Group 1

Further monthly developments for the diary score can be seen in Figure 0.2 as follows:

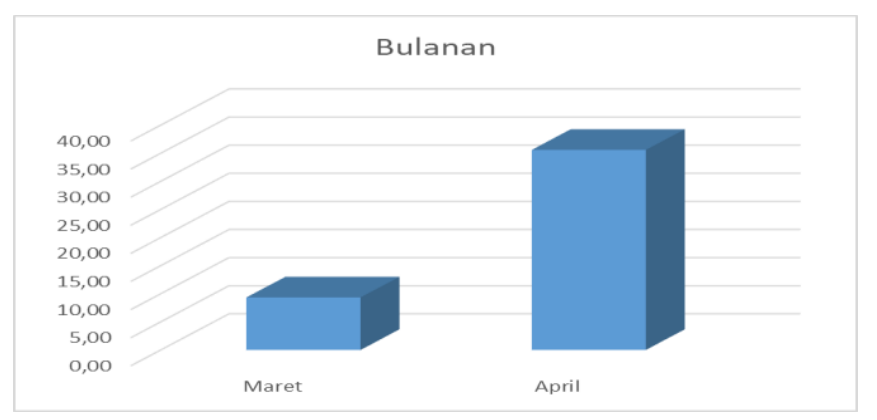

Fig. 2 Monthly Chart of Diary Scores in Experiment Group 1

Furthermore, diary score data for experiment group 2 will also be displayed in table 02 as follows:

Table 2. Weekly Score Diary in the Experiment Group 2

\begin{tabular}{|c|c|c|c|c|c|c|c|c|}
\hline & \multicolumn{7}{|c|}{ Day } & \multirow[t]{2}{*}{ Average } \\
\hline & 1 & 2 & 3 & 4 & 5 & 6 & 7 & \\
\hline M1 & 5,15 & 5,79 & 6,97 & 8,03 & 9,12 & 10,29 & 11,79 & 8,16 \\
\hline M2 & 12,03 & 14,12 & 16,03 & 17,94 & 19,76 & 21,65 & 23,47 & 17,86 \\
\hline M3 & 23,59 & 25,24 & 26,94 & 28,62 & 30,26 & 31,97 & 33,76 & 28,63 \\
\hline M4 & 33,88 & 35,56 & 37,29 & 39,06 & 40,79 & 42,44 & 44,21 & 39,03 \\
\hline M5 & 44,44 & 46,21 & 48,00 & 49,74 & 51,50 & 53,32 & 55,26 & 49,78 \\
\hline M6 & 55,18 & 56,91 & 58,68 & 60,38 & 62,12 & 63,94 & 65,76 & 60,42 \\
\hline
\end{tabular}

Further monthly developments for the diary score can be seen in Figure 0.3 as follows: 


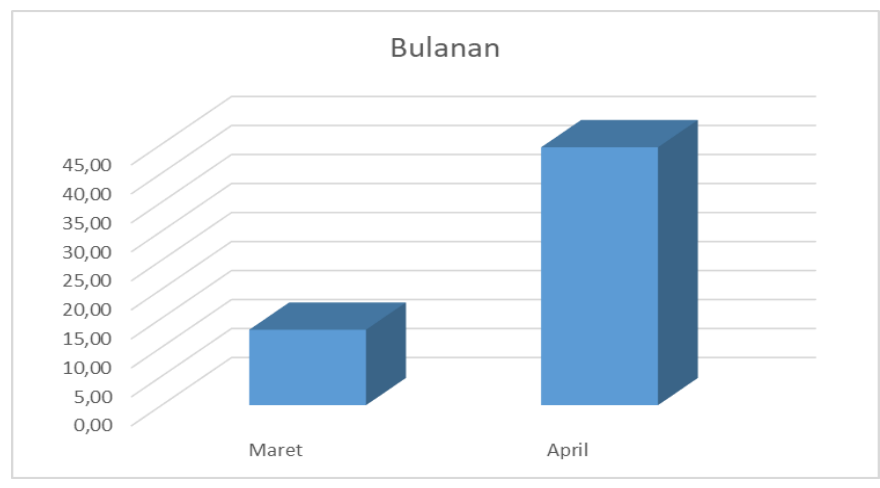

Fig. 3 Monthly Chart of Diary Score in Experiment Group 2

The next data that will be described is the recapitulation data of the results of the self-change questionnaire, pre-test and post-test, from Experiment 1,2, and Control groups in the table.

Table 3. Questionnaire Results Data Pre and Post test experimental groups 1, 2, and control groups.

\begin{tabular}{cccccccccc}
\hline \multirow{2}{*}{ No } & \multicolumn{3}{c}{ Klp Eksp 1 } & \multicolumn{3}{c}{ Klp Eksp 2 } & \multicolumn{3}{c}{ Kelompok Kontrol } \\
& Pre & Post & Gsn & Pre & Post & Gsn & Pre & Post & Gsn \\
\hline 1 & 151 & 165 & 0,26 & 148 & 164 & 0,28 & 149 & 150 & 0,02 \\
\hline 2 & 139 & 176 & 0,56 & 160 & 180 & 0,44 & 152 & 167 & 0,28 \\
\hline 3 & 126 & 145 & 0,24 & 173 & 190 & 0,53 & 156 & 176 & 0,41 \\
\hline 4 & 161 & 180 & 0,43 & 157 & 180 & 0,48 & 139 & 145 & 0,09 \\
\hline 5 & 130 & 168 & 0,51 & 158 & 189 & 0,66 & 124 & 151 & 0,33 \\
\hline 6 & 118 & 151 & 0,38 & 157 & 180 & 0,48 & 161 & 176 & 0,34 \\
\hline 7 & 164 & 180 & 0,39 & 146 & 167 & 0,36 & 139 & 172 & 0,50 \\
\hline 8 & 135 & 153 & 0,26 & 148 & 167 & 0,33 & 156 & 180 & 0,49 \\
\hline 9 & 162 & 173 & 0,26 & 142 & 179 & 0,59 & 157 & 176 & 0,40 \\
\hline 10 & 130 & 157 & 0,36 & 144 & 167 & 0,38 & 157 & 178 & 0,44 \\
\hline 11 & 155 & 163 & 0,16 & 144 & 179 & 0,57 & 157 & 181 & 0,50 \\
\hline 12 & 133 & 176 & 0,60 & 147 & 180 & 0,57 & 124 & 150 & 0,32 \\
13 & 136 & 164 & 0,41 & 158 & 180 & 0,47 & 159 & 164 & 0,11 \\
\hline 14 & 145 & 150 & 0,08 & 150 & 190 & 0,73 & 133 & 163 & 0,42 \\
15 & 137 & 138 & 0,01 & 167 & 180 & 0,34 & 149 & 170 & 0,38 \\
\hline 16 & 137 & 170 & 0,49 & 155 & 185 & 0,60 & 172 & 150 & $-0,67$ \\
\hline 17 & 154 & 176 & 0,43 & 163 & 187 & 0,57 & 139 & 160 & 0,32 \\
\hline 18 & 128 & 163 & 0,45 & 166 & 187 & 0,54 & 162 & 178 & 0,37 \\
\hline 19 & 118 & 172 & 0,62 & 150 & 187 & 0,67 & 149 & 184 & 0,63 \\
\hline 20 & 159 & 169 & 0,22 & 167 & 180 & 0,34 & 140 & 166 & 0,40 \\
\hline 21 & 131 & 165 & 0,46 & 141 & 164 & 0,36 & 152 & 160 & 0,15 \\
\hline 22 & 161 & 158 & $-0,07$ & 138 & 157 & 0,28 & 144 & 145 & 0,02 \\
\hline 23 & 151 & 151 & 0,00 & 167 & 179 & 0,32 & 154 & 141 & $-0,25$ \\
\hline 24 & 132 & 178 & 0,63 & 145 & 164 & 0,32 & 152 & 154 & 0,04 \\
\hline 25 & 140 & 158 & 0,28 & 179 & 190 & 0,42 & 150 & 143 & $-0,13$ \\
\hline 26 & 130 & 139 & 0,12 & 161 & 180 & 0,43 & 149 & 161 & 0,21 \\
\hline 27 & 123 & 147 & 0,29 & 165 & 185 & 0,50 & 144 & 153 & 0,15 \\
\hline 28 & 161 & 142 & $-0,43$ & 139 & 179 & 0,61 & 141 & 157 & 0,25 \\
\hline & & & & & & & & & \\
\hline
\end{tabular}




\begin{tabular}{cccccccccc}
\hline 29 & 157 & 157 & 0,00 & 148 & 180 & 0,56 & 139 & 137 & $-0,03$ \\
30 & 128 & 143 & 0,19 & 136 & 167 & 0,45 & 141 & 135 & $-0,09$ \\
31 & 152 & 163 & 0,21 & 144 & 179 & 0,57 & 150 & 145 & $-0,09$ \\
32 & 126 & 161 & 0,44 & 168 & 185 & 0,46 & 152 & 153 & 0,02 \\
33 & 119 & 148 & 0,34 & 157 & 180 & 0,48 & 154 & 151 & $-0,06$ \\
34 & 154 & 170 & 0,31 & 152 & 179 & 0,51 & 149 & 152 & 0,05 \\
& 4783 & 5469 & 9,89 & 5240 & 6066 & 16,20 & 5045 & 5424 & 6,30 \\
& & & & & & & & & 0,20 \\
Mean & 140,68 & 160,85 & 0,29 & 154,12 & 178,41 & 0,48 & 148,38 & 159,53 & 0,071 \\
\hline Varian & & & 0,050 & & & 0,014 & & & 0,071 \\
\hline
\end{tabular}

To meet the requirements of the hypothesis test, the data to be tested must first meet the requirements of normal distribution and homogeneity.

Data normality tests can be done with the chi-square test, lilliefors test, and Kolmogorov-Smirrnov test . In this study the normality test was carried out with the Kolmogorov-Smirrnov test with the help of SPSS 22 for Windows.

A homogeneity test is done to show that differences that occur in hypothesis testing occur due to differences between groups, not as a result of differences in groups. Homogeneity tests are also intended to show that two or more groups of sample data come from populations that have the same variance. To test the homogeneity of data variance in each group, it was carried out using the Levene's Test of Equality of Error Variance (Candiasa, 2004). This test can be done by using the help of SPPS 16.0 for Windows

Testing the hypothesis in this study using analysis of variance (ANOVA) of the track with the following provisions: In this $\mathrm{F}$ test will test the main effect (Main Effect) There can be two possibilities, namely $\mathrm{F}_{\mathrm{A}}$ (count) $>F_{\text {table }}$ ), meaning that the research results are significant, whereas if otherwise the research is not significant. If the Significant $\mathrm{F}$ must be followed by a t-scheffe test, to compare the effect between methods or techniques.

The results of calculations with one-way ANOVA can be seen in the following table, The results of the calculation of self-exchange data analysis with one-way analysis of variance in this study can be summarized as follows:

Table 4. Tests of Between-Subjects Effects

\begin{tabular}{lcrrrr}
\hline \multicolumn{1}{c}{ Source } & $\begin{array}{c}\text { Type III Sum } \\
\text { of Squares }\end{array}$ & df & Mean Square & F & Sig. \\
Corrected Model & $7554.882^{\mathrm{a}}$ & 2 & 3777.441 & 26.988 & .000 \\
Intercept & 2819683.147 & 1 & 2819683.147 & 20144.997 & .000 \\
X & 7554.882 & 2 & 3777.441 & 26.988 & .000 \\
Error & 13856.971 & 99 & 139.969 & & \\
Total & 2841095.000 & 102 & & & \\
Corrected Total & 21411.853 & 101 & & & \\
a. R Squared $=, 353$ (Adjusted R Squared $=, 340)$ & & & \\
\hline
\end{tabular}

Following the above analysis it turns out that $\mathrm{F} 0$ was obtained at 26,988 to test this F0 seen Ft (Ftable ) with $\mathrm{db}=1: 66$ turns out that Ft with $\mathrm{db} 3: 66$ at $\mathrm{p}=0.01(1 \%)$ amounted to 5.29 this means F0> Ft with $\mathrm{p}$ $<0.01$. so Ho was rejected and $\mathrm{H} 1$ accepted the results of the study were significant

\section{Hypothesis Testing 1}

Hypotheses 1 and 2

a) Hypothesis 1

H0 : Behavioral counseling model Modeling technique is not effective to improve self Change in class $\mathrm{X}$ students of SMK Negeri 3 Denpasar 
H1: Behavioral counseling model Effective modeling techniques to improve self Change in class $\mathrm{X}$ students of SMK Negeri 3 Denpasar

Based on the results of the t-test for behavioral counseling modeling techniques obtained tcount $=$ 3,913 , with $\mathrm{dk}(34+34)-2=66$ where $\mathrm{T}$ table $5 \%=1,671$ so that it can be concluded that modeling techniques are effective against increasing self-change

b) Hypothesis 2

H0: Behavioral counseling model The Social Skills Training technique is not effective to improve self Change in class X students of SMKNegeri 3 Denpasar

H1: Behavioral counseling model The effective Social Skills Training technique to improve selfChange in class X students of SMKNegeri 3 Denpasar

c) Hypothesis 3

H0 : There is no difference in the effectiveness of Behavioral counseling models with modeling techniques and Social Skills Training Techniques to improve self-change in class X students of SMK Negeri 3enpasar.

H1 : There is a difference in the effectiveness of Behavioral counseling models with modeling techniques and Social Skills Training Techniques to improve self Change in class X students of SMK Negeri 3 Denpasar.

Based on the results of the $\mathrm{t}$-test for behavioral counseling modeling techniques obtained data $\mathrm{t}$ count $=$ 1,32 with dk $(34+34)-2=66$ where $\mathrm{T}$ table $5 \%=2.869$ so it can be concluded that modeling techniques are not effective against increasing self-change

Based on the results of t-test calculations for behavioral counseling on social skills techniques, the t-test results are: 18.88 with $\mathrm{dk}(34=34)-2=66$ with $\mathrm{t}$ table $5 \%=2.869$ so it can be concluded that counseling Behavior techniques of social skills are effective for improving self-change.

So the conclusion is that there are differences in the effect of behavior counseling between modeling techniques and social skills techniques on self-change. The average self-change group of students who took the

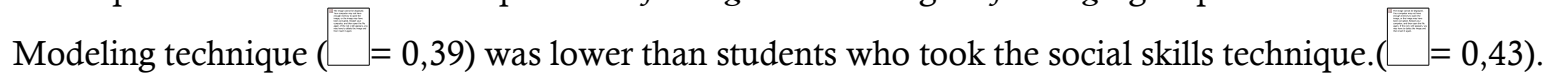

\section{Conclusion}

Self-change is someone's ability to make changes in a new direction, and change for the better, or become new and change from before. From the definition of self-change that was stated earlier, then selfchange contains indicators, namely: 1), something new and different, 2), traveling to new places, 3) meeting new people, 4) looking for new experiences, and changing them every day. Based on the results of data analysis and discussion of research results, the following conclusions can be drawn.

There are differences in the effectiveness of behavioral counseling modeling techniques with Social Skills techniques for self-change. Behavior Counseling is an effective social skills technique for increasing selfchange while modeling techniques are not effective for increasing self change.

\section{References}

Dharsana, Ketut.2013. Teori-Teori Konseling(Diktat).Singaraja:Jurusan Bimbingan Konseling Fakultas Ilmu Pendidikan Universitas Pendidikan Ganesha.

Dantes,Nyoman.2012.Metode Penelitian Yogyakarta.ANDI

Dantes,Nyoman.2014.Analisis dan Desain Eksperimen .Singaraja Program Pascasarjana Undiksha

Dharsana, Ketut. 2014. Model-model konseling, teori-teori konseling).

Dharsana, ketut.2014teori-teori Konseling (Diktat). Singaraja:Jurusan Bimbingan Konseling Fakultas Ilmu Pendidikan Universitas Pendidikan Ganesha. 
Dharsana, ketut. 2013 Dasar-dasar Bimbingan Konseling.Singaraja;Jurusan Bimbingan Konseling FIP Undiksha.

Dharsana, K. (2015). RPBK Seri 1 Bimbingan Klasikal,Bimbingan Kelompok,Konseling Kelompok,Konseling Individu Untuk Pengembangan Variabel Terikat Bakat Verbal. Singaraja: BK FIP Undiksha.

Dharsana, K. (2016)). Seri RPBK Seri Untuk Pengembangan Variabel Terikat Self.

Evia Dharmawanti. (2016). Modul Guru Bimbingan dan Konseling KK A. Direktorat Jendral Guru dan Tenaga Kependidikan Kementrian Pendidikan dan kebudayaan.

Maharani, L., \& Damayanti, R. (2012). Social Skill Training: Latihan Keterampilan Sosial Pada Anak Usia Dini Yang Mengalami Isolasi Sosial Pasca Bencana.

Nursalim, M. (2013). strategi dan intervensi konseling. Jakarta: Akademia Permata.

Purwanto, E., Zaenudin, Anggoro, H. B., Hidayat, selvia tristianty, \& Aisyah, S. (2016). Modul Kompetensi F Profesional : Implementasi Teori Konseling.

Romlah, T. (2006). Teori dan Praktek Bimbingan Kelompok. Malang: Universitas Negeri Malang

Article Information (Supplementary)

\begin{tabular}{|c|c|}
\hline & Conflict of Interest Disclosures: \\
\hline & $\begin{array}{l}\text { The authors declare that they have no significant competing } \\
\text { financial, professional or personal interests that might have } \\
\text { influenced the performance or presentation of the work described } \\
\text { in this manuscript. }\end{array}$ \\
\hline Copyrights Holder: <Andayani $><2020>$ & $\begin{array}{l}\text { First Publication Right: BISMA The Journal of } \\
\text { Counseling }\end{array}$ \\
\hline
\end{tabular}

http://dx.doi.org/10.23887/bisma.v3i1

First Publication Right: BISMA The Journal of

Open Access Article | CC-BY Creative Commons Attribution 4.0 International License.

@creative

Word Count: 4741 